$\begin{array}{lrlrllrr}\text { Volume } & 13, \quad \text { Nomor } & 1, \quad \text { Mei } & \text { 2021, } & \text { pp } & 173-187 & \text { Copyright } & \text { C } 2017 \\ \text { Jurnal } & \text { Akuntansi, } & \text { Program } & \text { Studi } & \text { Akuntansi, } & \text { Fakultas } & \text { Bisnis, } \\ \text { Universitas } & \text { Kristen } & \text { Maranatha. } & \text { ISSN } & 2085-8698 & \text { e-ISSN } & 2598-4977 .\end{array}$

http://journal.maranatha.edu

\title{
Pengaruh Struktur Kepemilikan Terhadap Kinerja Perusahaan Dimoderasi Oleh Karakteristik Dewan Komisaris
}

\author{
Ilham Maulana ${ }^{1}$ \\ Magister Manajemen, Fakultas Ekonomi dan Bisnis, Universitas Trunojoyo Madura \\ (Bangkalan) \\ ilhammlna01@gmail.com \\ Muhammad Alkirom Wildan ${ }^{2}$ \\ Magister Manajemen, Fakultas Ekonomi dan Bisnis, Universitas Trunojoyo Madura \\ (Bangkalan) \\ Email : wildan.alkirom@trunojoyo.ac.id \\ Nurita Andriani ${ }^{3}$ \\ Magister Manajemen, Fakultas Ekonomi dan Bisnis, Universitas Trunojoyo Madura \\ (Bangkalan) \\ Email : nurita@trunojoyo.ac.id
}

\begin{abstract}
This study was conducted to examine the effect of proxied ownership structure using institutional ownership, foreign ownership and managerial ownership variables which are moderated by the characteristics of the board of commissioners as proxied by the size of the board of commissioners, and the proportion of independent board of commissioners on company performance as measured by the firm's financial performance. Proxied by return on assets and return on equity and firm value proxied by Tobin's $Q$ and market to book ratio. With a total of 81 samples from financial service companies listed on the IDX in 2018 tested using WarpPLS 7.0, the researchers found that ownership structure has a negative effect on financial performance and firm value, the characteristics of the board of commissioners have a positive effect on financial performance and firm value, and only interaction characteristics the board of commissioners in the relationship between ownership structure and financial performance which can be a moderating variable.
\end{abstract}

Keywords: Ownership Structure, Firm Performance, and Characteristics of The Board of Commissioners. 


\begin{abstract}
Abstrak
Penelitian ini dilakukan untuk menguji pengaruh struktur kepemilikan diproksikan dengan menggunakan varibel kepemilikan institusional, kepemilikan asing, dan kepemilikan manajerial yang dimoderasi oleh karakteristik dewan komisaris yang diproksikan dengan variabel ukuran dewan komisaris, dan proporsi dewan komisaris independen terhadap kinerja perusahaan yang diukur oleh kinerja keuangan perusahaan yang diproksikan dengan return on asset dan return on equity dan nilai perusahaan yang diproksikan dengan Tobin's $Q$ dan market to book ratio. Dengan total 81 sampel dari perusahaan jasa keuangan yang terdaftar di BEI pada tahun 2018 diuji menggunakan WarpPLS 7.0. Peneliti menemukan bahwa struktur kepemilikan memiliki pengaruh negatif terhadap kinerja keuangan dan nilai perusahaan, karakteristik dewan komisaris berpengaruh positif terhadap kinerja keuangan dan nilai perusahaan, dan hanya interaksi karakteristik dewan komisaris dalam hubungan struktur kepemilikan dengan kinerja keuangan yang dapat menjadi variabel moderasi.
\end{abstract}

\title{
Kata Kunci: Struktur Kepemilikan, Kinerja Perusahaan, Karakteristik Dewan Komisaris
}

\section{Pendahuluan}

Konflik keagenan muncul karena adanya pemisahan antara kontrol perusahaan dan kepemilikan perusahaan, dimana agen harus mencapai suatu satuan kinerja tertentu sesuai dengan kontrak yang disepakati antara prinsipal dengan agen (Jensen \& Meckling, 1976). Agen atau manajer suatu perusahaan diharapkan mampu menghasilkan keuntungan dan kesejahteraan sebesarbesarnya kepada pemilik saham ataupun stakeholder secara umum. Manajer perusahaan merupakan profesional dalam mengelola perusahaan, mereka dipekerjakan dengan asumsi dapat meningkatkan efisiensi dari kinerja perusahaan. Namun dalam kenyataannya, banyak manajer yang cenderung mengejar tujuan pribadi mereka dengan memanfaatkan fasilitas dari perusahaan dan kekayaan pemilik perusahaan (Abbas et al., 2013)

Dalam teori agensi, struktur kepemilikan atau prinsipal memiliki peranan sangat penting karena kemampuannya untuk memengaruhi keputusan manajemen lewat pemungutan suara pemegang saham. Meski begitu peran pemilik saham memiliki batasan di mana mereka tidak bisa terlibat langsung dalam keputusan-keputusan penting yang bersifat teknis (Rashid, 2020). Semakin besar kepemilikan saham, maka semakin besar pula hak dalam pengendalian perusahaan dan yang dimaksud pengendalian disini adalah seberapa besar kemampuan pemilik saham dalam memengaruhi operasi perusahaan dan manajemen (Yeh, 2019). Fungsi pengendalian tersebut dapat langsung memengaruhi tindakan manajer yang tidak sesuai dengan harapan pemilik saham, agar manajer bertindak dalam rangka memenuhi ekspektasi dari pemilik saham.

Namun, struktur kepemilikan saham masih menjadi perdebatan di antara peneliti mengenai hubungan struktur kepemilikan dengan kinerja perusahaan. Mayoritas peneliti berpendapat jika struktur kepemilikan memiliki hubungan positif terhadap kinerja perusahaan, seperti kepemilikan asing berpengaruh positif terhadap kinerja perusahaan dalam penelitian Greenaway et al. (2014); Yavas, C. V., \& Erdogan (2017), dan berpengaruh negatif dalam penelitian Anh et al (2018), kepemilikan institusi berpengaruh positif terhadap kinerja perusahaan dalam Esther et al. (2016); Singh \& Kansil (2018) sedangkan 
dalam penelitian Tsouknidis (2019), kepemilikan institusi ditemukan berpengaruh negatif. Kepemilikan manajerial ditemukan berpengaruh positif dengan kinerja perusahaan (Bhagat \& Bolton, 2013; Westman, 2011). Sedangkan dalam Shan (2019) kepemilikan manajerial ditemukan berhubungan negatif.

Indonesia merupakan negara dengan pasar modal yang masih berkembang, tentunya berbeda dengan negara maju yang telah memiliki komitmen dan etika bisnis yang sangat tinggi, Indonesia masih tergolong baru dalam penerapan konsep corporate governance yang baik. Indonesia masih menjadi negara dengan perangkat dan penegakan hukum yang lemah dalam menangani pelanggaran hak-hak perusahaan (Wibowo, 2010). Perusahaan pada sektor jasa keuangan merupakan sektor yang memiliki aturan paling ketat, karena sektor ini diawasi langsung oleh pemerintah melalui otoritas jasa keuangan (OJK). Meskipun begitu bagi perusahaan di Indonesia khususnya sektor jasa keuangan yang ingin bertumbuh, penelitian ini akan memberikan gambaran bagaimana pengaruh restrukturisasi kepemilikan perusahaan dan karakteristik dewan akan memengaruhi perkembangan perusahaan.

Penelitian ini akan dikembangkan dari penelitian-penelitian sebelumnya yakni untuk mengetahui apakah karakteristik dewan yang diproksikan dengan ukuran dewan, dewan komisaris independen dapat memoderasi hubungan struktur kepemilikan dengan kinerja perusahaan. Dalam penelitian ini, untuk mengukur kinerja keuangan perusahaan akan menggunakan pengukuran akuntansi dengan return on asset (ROA) dan return on equity (ROE) sebagai alat ukurnya, dan pengukuran nilai perusahaan dengan Tobin's $Q$ dan Market to Book Ratio. Dengan Indonesia yang memiliki karakteristik corak tersendiri di antara negara yang menerapkan corporate governance diharapkan hasil penelitian ini berbeda dibanding negara lain.

\section{Kerangka Teoretis dan Hipotesis}

\section{Tinjauan Pustaka}

\section{Teori Agensi}

Teori agensi menjelaskan hubungan kontraktual antara agen (manajer perusahaan) dengan prinsipal (pemilik), dimana diberikan untuk mengelola perusahaan dan hak dalam memutuskan jalannya perusahaan. Namun, banyak dipercaya bahwa agen belum tentu melakukan aktivitas yang diinginkan prinsipal oleh karena itu prinsipal akan mengeluarkan sejumlah biaya untuk mengawasi kegiatan yang dilakukan oleh prnsipal (Jensen \& Meckling, 1976). Peran pengawasan prinsipal terhadap perusahaan akan dibantu dengan corporate governance yang menjaga check dan balance semua pihak yang terlibat di perusahaan.

\section{Corporate Governance}

Corporate governance merupakan seperangkat mekanisme yang digunakan untuk menjaga hubungan kontraktual antara agen dengan prinsipalnya. Agen yang diharuskan menciptakan kesejahteraan bagi pemilik perusahaan dapat bekerja secara efisien dengan penuh tanggung jawab untuk memenuhi kebutuhan prinsipal, begitu pula prinsipal harus memenuhi kebutuhan agen dalam usahanya menjalankan perusahaan. Corporate governance memastikan bahwa tidak ada kesalahan-kesalahan strategis perusahaan dan sesegera mungkin memperbaikinya (Mufidah \& Purnamasari, 2018).

Selain itu corporate governance merupakan alat untuk mengatur dan mengendalikan perusahaan dalam rangka menciptakan nilai tambah bagi perusahaan. Nilai tambah tersebut karena manajer perusahaan fokus untuk meningkatkan kinerja perusahaan karena ketatnya pengendalian dari mekanisme corporate governance. 
Unsur corporate governance yang digunakan dalam penelitian ini meliputi kepemilikan asing, kepemilikan manajerial, dewan komisaris.

\section{Kepemilikan Institusional}

Kepemilikan institusional merupakan kepemilikan saham yang dimiliki oleh institusi atau badan usaha. Institusi disini bisa berarti kepemilikan oleh bank, yayasan, pengelola dana investasi, pengelola dana pensiun, dan lainnya. Kepemilikan institusional memiliki kemampuan lebih baik dibanding dengan pemegang saham lainnya, karena kepemilikan dikelola oleh profesional dalam bidangnya, sehingga memiliki kemampuan pengawasan yang baik.

Di Indonesia, konsentrasi kepemilikan perusahaan dimiliki oleh institusi oleh pemilik institusional (Indarti \& Extaliyus, 2013) yang berarti mayoritas perusahaan di Indonesia memiliki pengawasan yang baik.

\section{Kepemilikan Asing}

Kepemilikan asing adalah kepemilikan saham suatu badan atau perorangan yang berkedudukan di luar negeri. Keberadaan pemilik yang berasal dari luar negeri tentunya akan membawa dampak yang baik terhadap perusahaan, karena perusahaan tersebut bisa jadi diawasi oleh pemilik yang memiliki etos kerja yang berbeda dengan negara domestik perusahaan. Dibandingkan dengan kepemilikan domestik, kepemilikan asing memiliki kemampuan yang lebih baik dalam mengurangi konflik agensi, antara pemilik saham dengan manajemen (AlGamrh et al., 2020).

\section{Kepemilikan Manajerial}

Kepemilikan manajerial merupakan kepemilikan saham yang dimiliki oleh individu atau kelompok internal perusahaan (Sugianto \& Sjarief, 2018). Kepemilikan bisa dimiliki oleh direktur dan komisaris suatu perusahaan. Kepemilikan manajerial diharapkan konflik agensi tidak terjadi karena manajer juga berlaku sebagai pemilik 176 perusahaan, yang mana mengharapkan kinerja yang baik dari perusahaan.

\section{Dewan Komisaris}

Dewan komisaris merupakan unsur pengendalian internal perusahaan (Maulana, 2020). Dalam penelitian ini baik dewan komisaris dengan dewan komisaris independen memiliki fungsi yang sama, yakni pengawasan dan pengendalian mengenai kinerja perusahaan. Hal yang membedakan keduanya adalah status independen yang melekat pada komisaris independen, yang artinya dia tidak memiliki ikatan apapun dengan perusahaan kecuali sebagai profesional dan perpanjangan tangan pemilik saham perusahaan.

\section{Kinerja Perusahaan}

Rashid (2020) memisah kinerja menjadi dua macam, yakni kinerja yang berdasarkan akuntansi seperti return on asset (ROA) dan return on equity (ROE), dan berdasarkan kinerja pasar seperti Tobin's Q dan market to book ratio (MTB). Rasio ROA digunakan untuk mengukur efisiensi perusahaan dalam menghasilkan laba berdasarkan total aset. ROE digunakan untuk mengukur efisiensi perusahaan untuk menghasilkan laba dengan memanfaatkan model perusahaan.

Pengukuran berdasarkan kinerja pasar dengan Tobin's Q dan MTB dimaksudkan untuk mengetahui apakah perusahaan dihargai undervalued, mencapai equlibrium atau overvalued dari harga wajarnya.

\section{Pengembangan Hipotesis}

\section{Struktur Kepemilikan dan Kinerja Perusahaan}

Konflik keagenan adalah keniscayaan dalam perusahaan, hal ini karena ada investor yang menyerahkan dananya untuk dikelola oleh perusahaan dan perusahaan yang diharuskan memberikan keuntungan kepada investor (Shleifer \& Vishny, 1997). Namun bukan berarti perusahaan pasti menghasilkan keuntungan bagi investor, karena manajer perusahaan juga memiliki kepentingan di 
dalamnya. Bagi seorang manajer yang terpenting adalah mereka mendapatkan gaji dan insentif setiap bulan dari perusahaan tanpa harus memikirkan keuntungan perusahaan. Oleh karena itu corporate governance ada sebagai mekanisme atau aturan main bagi perusahaan dalam menjalankan perusahaanya, sehingga kepentingan investor dan perusahaan dapat terpenuhi.

Investor dapat berupaya untuk mengurangi konflik keagenan dengan mengatur konsentrasi dari kepemilikan dalam sebuah perusahaan. Investor institusi punya peranan besar dalam konsentrasi kepemilikan saham, karena mereka menghimpun dana dari orang-orang yang menginvestasikan dananya dan berharap akan diputar oleh investor institusi dan karena mereka berkaitan dengan banyak orang mereka cenderung aktif mengawasi perusahaan yang mereka investasikan (Annuar, 2015) dan karena mereka aktif sebagai pemegang saham mayor, mereka memungkinkan untuk menyelesaikan masalah keagenan yang terjadi di dalam perusahaan sehingga perusahaan bisa lebih fokus dalam meningkatkan kinerja keuangan mereka, ini sejalan dengan apa yang ditemukan Kao et al, (2018) yang menyatakan kepemilikan institusi berpengaruh positif kepada kinerja perusahaan.

Perusahaan dengan corporate governance yang baik akan menarik minat investor untuk menginvestasikan dananya, karena melihat jaminan dari kepemilikan institusional yang akan turut membantu mengamankan dana investasi mereka. Sebagaimana Edmans (2009) menemukan bahwa kepemilikan dalam jumlah besar cenderung lebih mudah memonitor kinerja perusahaan karena jika perusahaan cenderung berkinerja jelek, pemilik blok akan melakukan penjualan saham dan hal ini memengaruhi kinerja pasar modal perusahaan. Dalam hal ini perusahaan didorong untuk terus menerus berada pada strategi kompetitif untuk menjaga daya saing dan menjamin para investor tersebut tidak menjual saham-saham mereka. Hutchinson, Seamer, \& Chapple (2015) menyatakan ketika pemilik institusi melakukan divestasi ini berarti sinyal bagi investor lain untuk segera exit dari kepemilikan saham.

Perusahaan dengan potensi pertumbuhan yang baik akan menarik minat investor asing. Hal ini karena investor asing cukup selektif dalam menentukan perusahaan mana yang akan ditanami modal, dan tujuan mereka semata-mata hanya mencari keuntungan dari investasi yang mereka tanam (Nakano \& Nguyen, 2013). Keberadaan investor asing ditemukan sangat berpengaruh positif terhadap kinerja perusahaan di pasar modal (Black et al, 2015) dan juga investor asing juga mendorong kinerja perusahaan (Omran et al., 2008; Yavas, C. V., \& Erdogan, 2017) .

Secara logika konsentrasi kepemilikan saham memungkinkan untuk bagi pemegang saham untuk secara langsung melakukan supervisi terhadap kinerja perusahaan. Kepemilikan saham oleh komisaris perusahaan memungkinkan baik pemegang saham dan manajemen meminimalisir konflik keagenan, hal ini karena komisaris turut memiliki kepentingan dalam kekayaan perusahaan. Namun hasil penelitian terdahulu masih terdapat gap hasil penelitian, seperti Westman (2011) yang menyatakan kepemilikan oleh manajemen berpengaruh positif terhadap kinerja keuangan perusahaan. Sejalan dengan ini, Bhagat \& Bolton (2013); Kao et al. (2018), dan Rashid (2020) menemukan kepemilikan oleh manajemen berpengaruh positif terhadap kinerja keuangan dan kinerja pasar modal dan berpendapat jika perusahaan ingin meningkatkan kinerja perusahaan mereka bisa melakukan restrukturisasi kepemilikan perusahaan. Namun berbanding terbalik dengan hasil dari George (2019) yang justru menemukan berpengaruh negatif. Hal ini menjadi alasan peneliti untuk meneliti hubungan kepemilikan komisaris dengan kinerja perusahaan karena ketika kepentingan perusahaan dan pemilik modal 
sudah sejalan, ternyata masih terdapat gap hasil penelitian. Dalam penelitian ini peneliti memiliki hipotesa bahwa Struktur Kepemilikan (OWN) dapat berpengaruh positif terhadap kinerja keuangan dan nilai perusahaan.

H1a: Struktur kepemilikan (OWN) dapat berpengaruh positif signifikan terhadap kinerja keuangan (FIN).

H1b: Struktur kepemilikan (OWN) dapat berpengaruh positif signifikan terhadap nilai perusahaan (VAL).

Keberadaan dewan komisaris dalam sebuah perusahaan dapat berfungsi sebagai kontrol terhadap aktivitas dan keputusan yang akan dibuat oleh perusahaan, dengan otoritasnya sebagai jabatan yang dapat memecat, dan mempekerjakan top level management (Ren et al, 2012). Kontrol ini dapat berupa pengawasan terhadap strategi perusahaan dan alokasi penggunaan sumber daya yang dimiliki perusahaan agar dapat digunakan seoptimal mungkin untuk kepentingan stake holder (Goodstein et al, 1994). Pengawasan ini bergantung dari seberapa banyak anggota dewan dan jumlah dewan komisaris independen. Penelitian terdahulu mengenai peran karakteristik dewan menemukan jumlah anggota dewan komisaris dapat berpengaruh positif terhadap kinerja perusahaan karena mampu memonitor dan mengarahkan manajer dalam menjalankan perusahaan (Adeabah et al, 2019; Tulung \& Ramdani, 2018). Namun, jumlah dewan komisaris yang terlalu banyak justru dapat berdampak negatif terhadap kinerja perusahaan karena lebih sulit dalam membuat keputusan secepatnya (Kao et al., 2019).

Penelitian terdahulu mengenai keberadaan dewan komisaris independen dalam hubungannya dengan kinerja perusahaan masih menunjukkan hasil yang belum pasti, Meah \& Chaudhory (2019) dan Tulung \& Ramdani (2018) menemukan adanya dewan komisaris independen menunjukkan hubungan positif terhadap 178 kinerja perusahaan, dan menganggap semakin banyak dewan independen akan semakin baik bagi perusahaan, sedangkan Adeabah et al. (2019) justru menemukan sebaliknya.

Dewan komisaris memiliki tugas untuk melindungi kepentingan yang dimiliki oleh pemegang saham, dan sebagaimana pemegang saham yang ingin perusahaan miliknya berkembang dewan komisaris memiliki andil dalam memastikan perusahaan tersebut berjalan sesuai dengan visi-misi perusahaan. Sebagaimana struktur kepemilikan dapat berpengaruh positif terhadap kinerja perusahaan (Bhagat \& Bolton, 2013; Greenaway et al., 2014; Singh \& Kansil, 2018), dewan komisaris dapat memperkuat pengaruh tersebut karena dewan komisaris merupakan perpanjangan tangan pemilik saham perusahaan, sebagai mana Wijaya et al. (2020) membuktikan dewan komisaris berpengaruh positif terhadap kinerja perusahaan, yang mana ini berarti dewan komisaris dapat mengontrol dan mengawasi kinerja perusahaan dengan baik. Pengawasan ini memastikan manajer tidak melakukan tindakan berbahaya yang mengancam perusahaan. Oleh karena itu maka peneliti membangun hipotesis sebagai berikut:

H2a: Karakteristik Dewan Komisaris berpengaruh Positif signifikan terhadap Kinerja Keuangan.

H2b: Karakteristik Dewan Komisaris berpengaruh Positif signifikan terhadap nilai Perusahaan.

H3a: Karakteristik Dewan Komisaris dapat memoderasi secara positif pengaruh Kepemilikan terhadap Kinerja Keuangan.

H3b: Karakteristik Dewan Komisaris dapat memoderasi secara positif pengaruh Kepemilikan terhadap Perusahaan. 


\section{Metode Penelitian}

\section{Jenis Penelitian}

Penelitian ini termasuk jenis penelitian kausal karena penelitian ini dilakukan untuk menguji pengaruh variabel independen (kepemilikan institusional, kepemilikan asing, kepemilikan manajerial), moderator karakteristik dewan komisaris (ukuran dewan komisaris, dewan komisaris independen) terhadap variabel dependen (ROA Tobin's $Q$ ) pada perusahaan sektor perbankan dan keuangan yang terdaftar di BEI dengan periode pengamatan 2016-2018.

\section{Variabel Independen}

Dalam perkembangan CG struktur kepemilikan memiliki peranan yang sangat penting dalam perusahaan karena memiliki kemampuan dalam memengaruhi keputusan perusahaan melalui pemungutan suara. Struktur kepemilikan dapat dianalisa berdasarkan konsentrasi kepemilikan dan identitas kepemilikan (Kumar \& Zattoni, 2015). Dalam penelitian ini struktur kepemilikan akan diproksikan dengan kepemilikan institusional, kepemilikan asing, kepemilikan manajerial.

Ukuran dewan komisaris, dan proporsi dewan komisaris independen adalah salah satu mekanisme CG yang sering diteliti belakangan ini, karena keduanya memiliki kemampuan untuk mengawasi operasi dan keputusan perusahaan (Tulung \& Ramdani, 2018).

Dalam penelitian ini variabel yang akan digunakan yakni kepemilikan institusi (INST), kepemilikan asing (FOREIGN), kepemilikan manajerial (BOARD), board size (BSIZE), dan board independence (BINDEP).

\section{Variabel Dependen}

Dalam penelitian ini pengukuran kinerja perusahaan berbasis akuntansi yakni ROA, dan berbasis pasar yakni Tobin's Q (TOBIN). ROA digunakan oleh investor untuk mengukur kinerja perusahaan sebelum mereka menginvestasikan modalnya. ROA dihitung dengan membagi laba setelah pajak dengan total aset. Tobin's Q diukur dengan rasio nilai kapitalisasi pasar ditambah total liabilitas dibagi total aset.

Semua variabel akan digambarkan pada tabel 1 .

Tabel 1

Definisi Variabel

\begin{tabular}{|c|c|c|}
\hline Variabel & Singkatan & Definisi Variabel \\
\hline $\begin{array}{l}\text { Kepemilikan } \\
\text { Institusi }\end{array}$ & INST & $\begin{array}{l}\text { Persentase } \\
\text { kepemilikan institusi }\end{array}$ \\
\hline $\begin{array}{l}\text { Kepemilikan } \\
\text { Asing }\end{array}$ & FOREIGN & $\begin{array}{l}\text { Persentase } \\
\text { kepemilikan asing }\end{array}$ \\
\hline $\begin{array}{l}\text { Kepemilikan } \\
\text { Manajerial }\end{array}$ & BOARD & $\begin{array}{l}\text { Persentase } \\
\text { kepemilikan } \\
\text { komisaris } \\
\text { direktur }\end{array}$ \\
\hline $\begin{array}{l}\text { Ukuran } \\
\text { Dewan } \\
\text { Komisaris }\end{array}$ & BSIZE & $\begin{array}{l}\text { Logaritma alami dari } \\
\text { total dewan komisaris }\end{array}$ \\
\hline $\begin{array}{l}\text { Dewan } \\
\text { Komisaris } \\
\text { Independen }\end{array}$ & BINDEP & $\begin{array}{l}\text { Persentase dewan } \\
\text { komisaris independen }\end{array}$ \\
\hline ROA & $\mathrm{ROA}$ & $\begin{array}{l}\text { Rasio laba bersih } \\
\text { setelah } \\
\text { terhadap total aset }\end{array}$ \\
\hline Tobin's Q & TOBIN & $\begin{array}{lr}\text { Rasio } & \text { nilai } \\
\text { kapitalisasi } & \text { pasar } \\
\text { ditambah } & \text { total } \\
\text { liabilitas dibagi } & \text { total } \\
\text { aset } & \end{array}$ \\
\hline
\end{tabular}

\section{Populasi dan Sampel}

Populasi dalam penelitian ini adalah seluruh perusahaan keuangan yang terdaftar di BEI pada periode 2018. Sampel dalam penelitian ini yaitu perusahaan sektor keuangan yang terdaftar di BEI dengan periode pengamatan 2018 yang dipilih dengan purposive sampling dengan kriteria, pertama, data tersedia di periode 2018 dan kedua, tersedia data yang dibutuhkan dalam penelitian ini (Sugiyono, 2017).

\section{Teknik Analisa}

Penelitian ini dianalisa dengan statistik deskriptif dan metode PLS dengan bantuan dari aplikasi WarpPLS 7.0. Kepemilikan institusional, kepemilikan asing dan kepemilikan manajerial akan diwujudkan sebagai variabel latent secara formatif dengan simbol OWN. Return on asset dan 
return on equity secara formatif akan diwujudkan sebagai variabel latent dengan simbol FIN. Nilai perusahaan dengan variabel market to book dan Tobin's Q akan disimbolkan sebagai variabel latent dengan simbol VAL. Karakteristik dewan komisaris yang diukur dengan variabel ukuran dewan komisaris dan proporsi dewan komisaris independen akan disimbolkan sebagai COM. Data yang telah dikumpulkan akan diuji Goodness fit model, multikolinearitas menggunakan nilai VIF (Variance Inflation factor), outer model, inner model dan uji hipotesis menggunakan PLS. Penggunaan model formatif dalam penelitian ini ditujukan karena bentuk data yang digunakan dalam penelitian ini observable data (Solimun et al., 2017).

\section{Hasil Penelitian Dan Pembahasan}

\section{Hasil Penelitian \\ Statistik Deskriptif}

\section{Tabel 2}

Statistik Deskriptif

\begin{tabular}{|c|c|c|c|c|c|}
\hline \multicolumn{6}{|c|}{ Descriptive Statistics } \\
\hline & $\mathrm{N}$ & $\begin{array}{c}\text { Min } \\
\text {. }\end{array}$ & $\begin{array}{c}\text { Ma } \\
\text { x. }\end{array}$ & $\begin{array}{c}\mathrm{Me} \\
\text { an }\end{array}$ & $\begin{array}{c}\text { Std. } \\
\text { Deviati } \\
\text { on }\end{array}$ \\
\hline INST & $\begin{array}{l}8 \\
1\end{array}$ & 0,00 & ,94 & $\begin{array}{c}0,4 \\
8\end{array}$ & 0,29 \\
\hline $\begin{array}{l}\text { FOREI } \\
\text { GN }\end{array}$ & $\begin{array}{l}8 \\
1\end{array}$ & 0,00 & ,98 & $\begin{array}{c}0,2 \\
0\end{array}$ & 0,31 \\
\hline $\begin{array}{l}\text { BOAR } \\
\text { D }\end{array}$ & $\begin{array}{l}8 \\
1\end{array}$ & 0,00 & ,28 & $\begin{array}{c}0,0 \\
1\end{array}$ & 0,04 \\
\hline BSIZE & $\begin{array}{l}8 \\
1\end{array}$ & 0,69 & $\begin{array}{c}2,2 \\
0\end{array}$ & $\begin{array}{c}1,3 \\
5\end{array}$ & 0,43 \\
\hline $\begin{array}{l}\text { BINDE } \\
\mathrm{P}\end{array}$ & $\begin{array}{l}8 \\
1\end{array}$ & 0,00 & $\begin{array}{c}1,0 \\
0\end{array}$ & $\begin{array}{c}0,5 \\
3\end{array}$ & 0,18 \\
\hline ROA & $\begin{array}{l}8 \\
1\end{array}$ & $\begin{array}{c}- \\
12,9 \\
4\end{array}$ & $\begin{array}{l}17, \\
00\end{array}$ & $\begin{array}{c}2,0 \\
6\end{array}$ & 4,45 \\
\hline ROE & $\begin{array}{l}8 \\
1\end{array}$ & $\begin{array}{c}- \\
126, \\
00\end{array}$ & $\begin{array}{l}28, \\
40\end{array}$ & $\begin{array}{c}2,5 \\
1\end{array}$ & 18,83 \\
\hline TOBIN & $\begin{array}{l}8 \\
1\end{array}$ & 0,22 & $\begin{array}{l}17, \\
00\end{array}$ & $\begin{array}{c}1,5 \\
5\end{array}$ & 2,54 \\
\hline MTB & $\begin{array}{l}8 \\
1\end{array}$ & 0,17 & $\begin{array}{l}17, \\
58\end{array}$ & $\begin{array}{c}1,9 \\
8\end{array}$ & 2,88 \\
\hline Valid N & $\begin{array}{l}8 \\
1\end{array}$ & & & & \\
\hline
\end{tabular}

Tabel 2 disajikan untuk memberikan gambaran data dalam penelitian ini. Total sampel yang digunakan dalam penelitian ini adalah 81 data.
Nilai minimal dari INST adalah 0.00, maksimal 0.94, mean 0.48 dan standar deviasi 0.29. Nilai minimal dari FOREIGN adalah 0.00 , maksimal 0.98 , mean 0.20 dan standar deviasi 0.31 Nilai minimal dari BOARD adalah 0.00, maksimal 0.28, mean 0.01 dan standar deviasi 0.04. Nilai minimal dari BSIZE adalah 0.69, maksimal 2.20, mean 1.35 dan standar deviasi 0.43 . Nilai minimal dari BINDEP adalah 0.00 , maksimal 1.00, mean 0.53 dan standar deviasi 0.18. Nilai minimal dari ROA adalah -12.94, maksimal 17.00, mean 2.06 dan standar deviasi 4.45. Nilai minimal dari ROE adalah $-126,00$, maksimal 2.84 , mean 2.51 dan standar deviasi 18.83. Nilai minimal dari TOBIN adalah 0.22, maksimal 0.17, mean 1.55 dan standar deviasi 2.54, dan Nilai minimal dari MTB adalah 0.17, maksimal 17.58, mean 1.98 dan standar deviasi 2.88.

\section{Penilaian Outer Model}

Dalam penelitian ini terdapat masalah dalam pengujian model yang telah dilakukan di mana variabel OWN dan VAL tidak memenuhi syarat dalam pengujian outer model sebagaimana yang dijelaskan oleh Kock (2014), nilai signifikansi dari indikator kurang dari 0,05 dan VIF sesuai dengan rule of thumb 3.3. Pada pengujian pertama nilai signifikansi BOARD sebesar 0.068 lebih dari 0,05 dan VIF MTB dan TOBIN sebesar 9.147 lebih dari 3.3, sehingga peneliti drop dua indikator tersebut.

Selanjutnya, peneliti melakukan pengujian ulang dan mendapatkan hasil seperti tabel 3 . 
Tabel 3

Significance of Weight

\begin{tabular}{|c|c|c|c|c|}
\hline \multicolumn{5}{|c|}{ Significance of Weight } \\
\hline \multicolumn{2}{|c|}{ Variabel } & Tipe & $\mathbf{P}$ & VIF \\
\hline \multirow[t]{2}{*}{ OWN } & FOREIGN & $\begin{array}{c}\text { Formativ } \\
\mathrm{e}\end{array}$ & $<0.001$ & $\begin{array}{c}2.02 \\
0\end{array}$ \\
\hline & INST & $\begin{array}{c}\text { Formativ } \\
\mathrm{e}\end{array}$ & $<0.001$ & $\begin{array}{c}2.02 \\
0\end{array}$ \\
\hline \multirow[t]{2}{*}{ COM } & BSIZE & $\begin{array}{c}\text { Formativ } \\
\mathrm{e}\end{array}$ & $<0.001$ & $\begin{array}{c}1.02 \\
1\end{array}$ \\
\hline & BINDEP & $\begin{array}{c}\text { Formativ } \\
\mathrm{e}\end{array}$ & $<0.001$ & $\begin{array}{c}1.02 \\
1\end{array}$ \\
\hline \multirow[t]{2}{*}{ FIN } & ROA & $\begin{array}{c}\text { Formativ } \\
\mathrm{e}\end{array}$ & $<0.001$ & $\begin{array}{c}1.61 \\
0\end{array}$ \\
\hline & ROE & $\begin{array}{c}\text { Formativ } \\
\mathrm{e}\end{array}$ & $<0.001$ & $\begin{array}{c}1.61 \\
0\end{array}$ \\
\hline VAL & MTB & $\begin{array}{c}\text { Formativ } \\
\mathrm{e}\end{array}$ & $<0.001$ & $\begin{array}{c}0.00 \\
0\end{array}$ \\
\hline$\underset{\mathbf{N}}{\mathrm{COM}^{*} \mathrm{OW}}$ & $\begin{array}{l}\text { COM*OW } \\
\mathbf{N}\end{array}$ & $\begin{array}{c}\text { Reflectiv } \\
\mathrm{e}\end{array}$ & $<0.001$ & $\begin{array}{c}0.00 \\
0\end{array}$ \\
\hline
\end{tabular}

Dalam tabel 3 dapat dilihat bahwa setiap indikator memenuhi kriteria yang diajukan oleh Kock (2014) yang mana dalam model formative dalam menilai outer model dimana nilai signifikansi dari FOREIGN, INST, BSIZE, BINDEP, ROA, ROE, MTB dan interaksi COM dengan OWN adalah $<0.001$, yang artinya memenuhi nilai significance of weight.

Kemudian nilai VIF dengan menggunakan syarat dari Hair et al. (2019) dan Kock \& Lynn (2012) bahwa nilai VIF idealnya kurang dari 3.3 sesuai dengan rule of thumb. Indikator FOREIGN dan INST memiliki nilai VIF 2,020 kurang dari 3.3, BSIZE dan BINDEP 1,021 kurang dari 3.3, ROA dan ROE memiliki nilai VIF 1,610 kurang dari 3.3. MTB memiliki VIF 0.00 kurang dari 3.3, dan $\mathrm{COM}^{*} \mathrm{OWN} 0.00$.

Maka dapat disimpulkan pengujian ini memenuhi syarat outer model.

\section{Penilaian Inner Model}

Inner model akan dinilai dengan melihat nilai dari $\mathrm{R}^{2}$ dan $\mathrm{Q}^{2}$ yang akan dipaparkan dalam tabel 4.
Tabel 4

Adjusted R-Squared dan Q-Squared

\begin{tabular}{|c|c|c|}
\hline Variabel & $\begin{array}{c}\text { Adjusted R- } \\
\text { squared }\end{array}$ & $\begin{array}{c}\text { Q- } \\
\text { Squared }\end{array}$ \\
\hline $\begin{array}{c}\text { Kinerja Keuangan } \\
\text { (FIN) }\end{array}$ & 0.088 & 0.177 \\
\hline $\begin{array}{c}\text { Nilai Perusahaan } \\
\text { (VAL) }\end{array}$ & 0.148 & 0.210 \\
\hline
\end{tabular}

Dalam tabel 4 nilai adjusted $R$-squared pada pengujian terhadap FIN sebesar 0,088 yang artinya variabel penjelas dapat memberikan pengaruh sebesar $8,8 \%$ yang mana terdapat $92,2 \%$ dijelaskan dengan variabel di luar penelitian ini, dan nilai $R$-squared dalam pengujian terhadap VAL sebesar 0,148 , artinya variabel penjelas dapat memengaruhi sebesar $14,8 \%$ dan terdapat $85,2 \%$ dijelaskan dengan variabel diluar penelitian ini.

Kemudian dalam menilai $Q$ squared akan sangat baik jika nilai $Q$ squared diatas 0,00 , karena artinya variabel memiliki nilai prediktif. Dalam pengujian terhadap FIN memiliki nilai $Q$-Squared sebesar 0,177 dan terhadap VAL sebesar 0,210 , artinya variabel penjelas memeiliki nilai prediktif.

\section{Goodness Fit Model}

Kemudian peneliti menilai dari pengujian WarpPLS 7.0 dengan Goodness fit model yang dihasilkan dari pengujian data.

Tabel 5

\section{Goodness Fit Model}

\begin{tabular}{|l|c|c|}
\hline \multicolumn{1}{|c|}{$\begin{array}{c}\text { Analisis General } \\
\text { Result }\end{array}$} & Ket. \\
\hline $\begin{array}{l}\text { Average path } \\
\text { coefficient (APC) }\end{array}$ & $\begin{array}{c}\mathrm{APC}=0.167 \\
\mathrm{P}=0.011\end{array}$ & $\begin{array}{c}\text { Baik jika P- } \\
\text { value }<0,05\end{array}$ \\
\hline $\begin{array}{l}\text { Average R-squared } \\
\text { (ARS) }\end{array}$ & $\begin{array}{c}\mathrm{ARS}=151, \\
\mathrm{P}=0.017\end{array}$ & $\begin{array}{c}\text { Baik jika P- } \\
\text { value }<0,05\end{array}$ \\
\hline $\begin{array}{l}\text { Average adjusted } \\
\text { R-squared (AARS) }\end{array}$ & $\begin{array}{c}\mathrm{AARS}=0.1 \\
18,\end{array}$ & $\begin{array}{l}\text { Baik jika P- } \\
\text { value }<0,05\end{array}$ \\
\hline $\begin{array}{l}\text { Average block VIF } \\
\text { (AVIF) }\end{array}$ & $\begin{array}{c}2.704, \text { ideal } \\
\text { jika }<3.3\end{array}$ & Ideal \\
\hline $\begin{array}{l}\text { Average full } \\
\text { collinearity VIF } \\
\text { (AFVIF) }\end{array}$ & $\begin{array}{c}1.167, \text { ideal } \\
\text { jika }<3.3\end{array}$ & Ideal \\
\hline
\end{tabular}


Dalam goodness fit model nilai APC, ARS, dan AARS akan dinilai baik jika memiliki nilai $P$ value di bawah 0,05 , dalam tabel 5 menunjukkan bahwa nilai APC, ARS dan AARS memiliki nilai di bawah 0,05. kemudian nilai AVIF dan AFVIF akan dinilai ideal jika di bawah 3.3, dalam tabel 5 menunjukkan bahwa nilai AVIF dan AFVIF berada di bawah 3.3.

Berikut merupakan gambaran model penelitian ini :

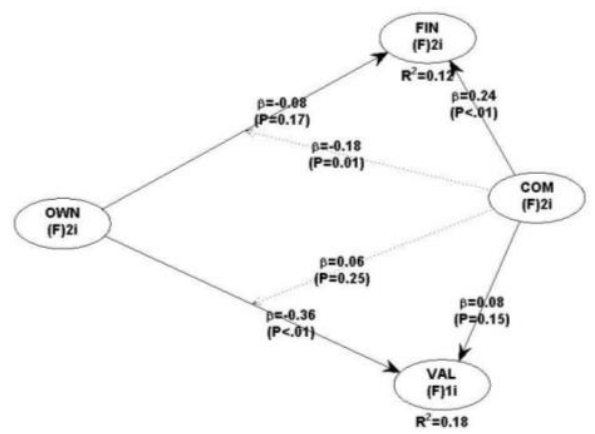

Gambar 1

Hasil Pengujian Dengan WarpPLS Sumber : Hasil Pengujian WarpPLS

Kemudian disajikan hasil dari pengujian dengan WarpPLS ke dalam tabel untuk mempermudah peneliti dalam menginterpretasi hasil analisis data.

Tabel 6

Hasil Pengujian Dengan WarpPLS

\begin{tabular}{|c|c|c|c|c|}
\hline $\begin{array}{l}\text { Keteranga } \\
\text { n }\end{array}$ & $\begin{array}{l}\text { Path } \\
\text { Coef. }\end{array}$ & $\begin{array}{l}\text { P- } \\
\text { Valu } \\
\text { e }\end{array}$ & $\begin{array}{l}\text { Ara } \\
\text { h }\end{array}$ & $\begin{array}{l}\text { Keputu } \\
\text { san }\end{array}$ \\
\hline OWN $>$ FIN & -0.079 & $\begin{array}{l}0.17 \\
1\end{array}$ & $\begin{array}{l}\text { Neg } \\
\text { atif }\end{array}$ & $\begin{array}{l}\text { H1a } \\
\text { Ditolak }\end{array}$ \\
\hline $\begin{array}{l}\mathrm{OWN}>\mathrm{VA} \\
\mathrm{L}\end{array}$ & -0.365 & $\begin{array}{l}<0.0 \\
01\end{array}$ & $\begin{array}{l}\text { Neg } \\
\text { atif }\end{array}$ & $\begin{array}{l}\text { H1b } \\
\text { Ditolak }\end{array}$ \\
\hline $\mathrm{COM}>\mathrm{FIN}$ & 0.238 & $\begin{array}{l}0.00 \\
2\end{array}$ & $\begin{array}{l}\text { Posi } \\
\text { tif }\end{array}$ & $\begin{array}{l}\mathrm{H} 2 \mathrm{a} \\
\text { Diterim } \\
\mathrm{a}\end{array}$ \\
\hline $\mathrm{COM}>\mathrm{VAL}$ & 0.085 & $\begin{array}{l}0.15 \\
3\end{array}$ & $\begin{array}{l}\text { Posi } \\
\text { tif }\end{array}$ & $\begin{array}{l}\mathrm{H} 2 \mathrm{~b} \\
\text { Ditolak }\end{array}$ \\
\hline $\begin{array}{l}\mathrm{COM}^{*} \mathrm{OW} \\
\mathrm{N}>\text { FIN }\end{array}$ & -0.182 & $\begin{array}{l}0.01 \\
5\end{array}$ & $\begin{array}{l}\mathrm{Neg} \\
\text { atif }\end{array}$ & $\begin{array}{l}\text { H3a } \\
\text { Ditolak }\end{array}$ \\
\hline $\begin{array}{l}\mathrm{COM} * \mathrm{OW} \\
\mathrm{N}>\mathrm{VAL}\end{array}$ & 0.055 & $\begin{array}{l}0.25 \\
1\end{array}$ & $\begin{array}{l}\text { Posi } \\
\text { tif }\end{array}$ & $\begin{array}{l}\mathrm{H} 3 \mathrm{~b} \\
\text { Ditolak }\end{array}$ \\
\hline
\end{tabular}

Dalam menilai signifikansi, penelitian ini menggunakan standar jika nilai $P$-value kurang dari 0,05 maka diputuskan memiliki pengaruh yang signifikan. Berdasarkan tabel 6, OWN ditemukan berpengaruh negatif tidak signifikan terhadap FIN dengan nilai koefisien -0.079 dan P-value 0.171 yang artinya H1a yang menyatakan Struktur Kepemilikan dapat berpengaruh positif signifikan terhadap kinerja keuangan, ditolak. OWN ditemukan berpengaruh negatif signifikan terhadap VAL dengan nilai koefisien -0.365 dan $P$ value $<0.001$ yang artinya $\mathrm{H} 1 \mathrm{~b}$ yang menyatakan kepemilikan dapat berpengaruh positif signifikan terhadap kinerja nilai perusahaan, ditolak.

COM ditemukan berpengaruh negatif signifikan terhadap FIN dengan nilai koefisien 0.238 dan P-value 0.002 yang artinya $\mathrm{H} 2 \mathrm{a}$ yang menyatakan kepemilikan dapat berpengaruh positif terhadap kinerja keuangan, diterima. COM ditemukan berpengaruh positif tidak signifikan terhadap VAL dengan nilai koefisien 0.085 dan Pvalue 0.153 yang artinya H1b yang menyatakan kepemilikan dapat berpengaruh positif terhadap kinerja nilai perusahaan, ditolak.

Mengenai peran memoderasi karakteristik dewan komisaris peneliti menggunakan syarat yang diajukan Baron \& Kenny (1986) yang menyebutkan jika hasil moderasi akan didukung jika variabel interaksi signifikan $p$-value $<0.05$. $\mathrm{COM}^{*} \mathrm{OWN}$ yang merupakan interaksi variabel COM dan OWN ditemukan berpengaruh negatif signifikan terhadap FIN dengan nilai koefisien -0.182 dan $p$-value 0.015 yang artinya $\mathrm{H} 3 \mathrm{a}$, ditolak karena tidak memoderasi secara positif hubungan OWN dengan FIN. COM*OWN ditemukan berpengaruh positif tidak signifikan terhadap VAL dengan nilai koefisien 0.055 dan $p$ value 0.251 yang artinya $\mathrm{H} 3 \mathrm{~b}$ ditolak karena nilai signifikansi moderasi lebih dari 0,05 .

Persamaan dalam penelitian ini dapat ditulis sebagai berikut : 


\section{FIN : -0.079 OWN +0.238 COM + -0,182 $\mathrm{COM} * \mathrm{OWN}$}

VAL : -0.365 OWN $+0.085 \mathrm{COM}+-0,055$ COM*OWN

\section{Pembahasan}

\section{Pengaruh Struktur Kepemilikan Terhadap Kinerja Perusahaan}

Struktur kepemilikan yang diharapkan dapat meningkatkan kinerja keuangan perusahaan dan nilai perusahaan ternyata memiliki pengaruh sebaliknya. Secara empiris dalam penelitian ini struktur kepemilikan memiliki pengaruh negatif terhadap kinerja keuangan perusahaan meskipun tidak signifikan, dan justru berpengaruh negatif signifikan terhadap nilai perusahaan. Bukti ini menandakan bahwa terjadinya konflik keagenan antara pemilik perusahaan dengan manajer perusahaan, menyebabkan manajer perusahaan tidak dapat mengelola perusahaan dengan efektif disebabkan terlalu besarnya pengaruh yang dimiliki oleh pemilik perusahaan.

Pasar juga merespon demikian, karena besarnya pengaruh dari kepemilikan mayoritas memberikan sinyal kepada pasar adanya kemungkinan besar kepentingan minoritas kurang didengar. Agen akan cenderung untuk mengikuti kemauan pemilik mayoritas karena mereka memiliki suara yang sangat berpengaruh untuk kebijakan perusahaan bahkan untuk tetap mempekerjakan direktur atau memberhentikan mereka. Terlalu besarnya pengaruh pemilik mayoritas mendorong menurunnya nilai perusahaan di pasar saham.

McColgan (2001) menjelaskan bahwa bahwa terjadinya konflik agensi di perusahaan dapat dilihat dari turunnya nilai perusahaan di pasar saham. Adanya perbedaan kepentingan antara pemilik saham dengan manajer merupakan sinyal buruk bagi calon investor karena perusahaan tersebut tidak mampu fokus pada tujuan awal perusahaan, yakni menghasilkan keuntungan bagi pemegang saham.

\section{Pengaruh Karakteristik Dewan} Komisaris Terhadap Kinerja Perusahaan Sebagai perpanjangan tangan dari pemilik perusahaan, dewan komisaris terbukti secara empiris dapat mengontrol manajer perusahaan untuk meningkatkan keuntungan dan meningkatkan kesejahteraan pemilik saham setinggi-tingginya. Peran pengawasan yang dilakukan oleh dewan komisaris mendorong manajer tidak melakukan kegiatan yang dapat menyebabkan perusahaan berada di posisi yang membahayakan.

Berdasarkan bukti empiris ini dapat dikatakan bahwa semakin banyak jumlah dewan komisaris dan komisaris independen akan meningkatkan kinerja keuangan perusahaan.

Dalam Wijaya et al. (2020) dijelaskan bahwa semakin banyak dewan komisaris sebuah perusahaan maka akan sebaik pula pengawasan dan pengendaliannya. Namun yang perlu diperhatikan jumlah dewan komisaris tidak boleh terlalu banyak karena akan memberikan masalah baru, seperti yang dijelaskan Kao et al. (2019) bahwa jika terlalu banyak akan mempersulit proses pengambilan keputusan. Dalam kasus Indonesia, jumlah dewan komisaris dan dewan komisaris independen berada pada jumlah yang optimal oleh karena itu dalam penelitian ini dewan komisaris dapat berpengaruh positif signifikan terhadap kinerja keuangan perusahaan.

Karakteristik dewan komisaris memberikan pengaruh positif meskipun tidak signifikan terhadap nilai perusahaan. Hal ini dapat dijelaskan dengan banyaknya dewan komisaris dan proporsi dewan komisaris dapat banyak orang tertarik untuk memiliki saham perusahaan karena percaya dananya dapat dikelola dengan bertanggungjawab oleh perusahaan. 


\section{Karakteristik Dewan Memoderasi Hubungan Struktur Kepemilikan dan Kinerja Perusahaan}

Berdasarkan hasil pengujian yang disajikan dalam tabel 6 , hanya variabel interaksi dari COM*OWN terhadap FIN yang dapat dikatakan memoderasi hubungan OWN dengan FIN. Dengan arah arah negatif dapat kita interpretasikan bahwa variabel interaksi tersebut akan memperlemah hubungan dari FIN dengan OWN. Sebagai mana kita ketahui bahwa OWN memiliki pengaruh negatif terhadap FIN, artinya pengaruh tersebut dapat dikurangi.

Keberadaan dewan komisaris di perusahaan dapat menjadi pihak yang menengahi hubungan antara pemilik dengan manajer. Keberadaan mereka dapat mengurangi pengaruh pemilik yang terlalu overpower yang dapat mengganggu manajer dalam menciptakan keuntungan perusahaan kinerja.

\section{Simpulan dan Saran}

\section{Simpulan}

Dalam penelitian ini ditemukan bukti secara empiris bahwa pengaruh kepemilikan saham pada kinerja perusahaan adalah negatif. Baik hubungan terhadap kinerja keuangan perusahaan maupun nilai perusahaan. Hal ini mengindikasikan pengaruh yang terlalu besar dari pemilik perusahaan kepada perusahaan akan mengurangi kinerja perusahaan, baik kinerja keuangan maupun nilai perusahaan. Tsouknidis (2019) berpendapat bahwa pengaruh negatif disebabkan oleh pemilik saham perusahaan menggunakan haknya untuk menekan manajer perusahaan dengan pengawasan yang berlebihan yang menunda proses pengambilan keputusan, yang mana akan mengganggu kinerja di masa yang akan datang.

Karakteristik dewan komisaris memiliki hubungan positif dengan kinerja perusahaan, baik kinerja keuangan dan nilai perusahaan, meskipun pengaruh terhadap nilai perusahaan tidak signifikan. Dengan begitu, dapat diasumsikan bahwa dengan banyaknya dewan komisaris dan komisaris independen, dapat mendorong kinerja perusahaan melalui pengawasannya. Hasil tersebut dengan hasil yang ditunjukkan oleh Tulung \& Ramdani (2018) dan Wijaya et al. (2020) yang menemukan dewan komisaris dapat mengawasi manajer dengan efisien untuk meningkatkan kinerja.

Interaksi karakteristik dewan komisaris dalam hubungan kepemilikan dengan kinerja keuangan dapat memperlemah hubungan tersebut. Namun dalam penelitian ini dapat dijelaskan dengan memperlemah dampak negatif dari pengaruh kepemilikan terhadap kinerja keuangan. Sedangkan dalam hubungan kepemilikan dengan nilai perusahaan, variabel moderasi tidak dapat memoderasi hubungan tersebut.

\section{Saran}

Bagi peneliti yang ingin melakukan penelitian serupa, sebaiknya menambahkan variabel kontrol untuk meningkatkan kualitas hasil pengujian. Dalam hal ini penelitian berikutnya dapat menambahkan umur perusahaan, ukuran perusahaan dan leverage. Selain itu peneliti berikutnya dapat menggunakan perusahaan dari pasar modal dari negara yang berbeda untuk memberikan perbandingan yang lebih luas tentang penerapan corporate governance.

\section{Daftar Pustaka}

Abbas, A., Naqvi, H. A., \& Mirza, H. H. (2013). Impact of large ownership on firm performance: A case of non financial listed companies of Pakistan. World Applied Sciences Journal, 21(8), 1141-1152. https://doi.org/10.5829/idosi.wasj.201 3.21.8.1916

Adeabah, D., Gyeke-Dako, A., \& Andoh, C. (2019). Board gender diversity, corporate governance and bank efficiency in Ghana: a two stage data envelope analysis (DEA) approach. Corporate Governance (Bingley), 
19(2), 299-320. https://doi.org/10.1108/CG-08-20170171

Al-Gamrh, B., Al-Dhamari, R., Jalan, A., \& Afshar Jahanshahi, A. (2020). The impact of board independence and foreign ownership on financial and social performance of firms: evidence from the UAE. Journal of Applied Accounting Research, 21(2), 201-229. https://doi.org/10.1108/JAAR-092018-0147

Anh, P. N., Phu, T. N., \& Nguyen, H. Y. (2018). Effect of foreign ownership on firm performance in Vietnam. Proceedings of the Eighteenth AsiaPacific Conference on Global Business, Economics, Finance \& Social Sciences (AP18Thailand Conference), 1-9.

Annuar, H. A. (2015). Changes in ownership forms and role of institutional investors in governing public companies in Malaysia A research note. Journal of Accounting and Organizational Change, 11(4), 455475. https://doi.org/10.1108/JAOC08-2012-0068

Baron, R. M., \& Kenny, D. A. (1986). The Moderator-Mediator Variable Distinction in Social Psychological Research: Conceptual, Strategic, and Statistical Considerations. Journal of Personality and Social Psychology, 51(6), 1173-1182. https://doi.org/10.1007/BF02512353

Bhagat, S., \& Bolton, B. (2013). Director ownership, governance, and performance. Journal of Financial and Quantitative Analysis, 48(1), 105135. https://doi.org/10.1017/S0022109013 000045

Black, B. S., Kim, W., Jang, H., \& Park, K. S. (2015). How corporate governance affect firm value? Evidence on a selfdealing channel from a natural experiment in Korea. Journal of Banking and Finance, 51, 131-150. https://doi.org/10.1016/j.jbankfin.201 4.08 .020

Edmans, A. (2009). Blockholder Trading, Market Efficiency, and Managerial Myopia. The Journal of Finance, $\operatorname{LXIV(6),\quad 2481-2513.}$ http://onlinelibrary.wiley.com/doi/10. 1111/j.1540-6261.2009.01508.x/full

Esther, W. G., Symon, K. K., Lawrence, K. K., \& Sifunjo, E. K. (2016). The influence of ownership structure on financial performance of privatized companies in Kenya. African Journal of Business Management, 10(4), 7588.

https://doi.org/10.5897/ajbm2015.794 9

Goodstein, J., Gautam, K., \& Boeker, W. (1994). the Effects of Board Size and Diversity on Strategic Change. Strategic Management Journal, 15(September 1993), 241-250. http://dx.doi.org/10.1002/smj.425015 0305

Greenaway, D., Guariglia, A., \& Yu, Z. (2014). The more the better? Foreign ownership and corporate performance in China. European Journal of Finance, 20(7-9), 681-702. https://doi.org/10.1080/1351847X.20 12.671785

Hair, J. F., Risher, J. J., Sarstedt, M., \& Ringle, C. M. (2019). When to use and how to report the results of PLS-SEM. European Business Review, 31(1), 224. https://doi.org/10.1108/EBR-112018-0203

Hutchinson, M., Seamer, M., \& Chapple, L. E. (2015). Institutional investors, risk/performance and corporate governance. International Journal of Accounting, 50(1), 31-52. https://doi.org/10.1016/j.intacc.2014. 12.004

Indarti, M. K., \& Extaliyus, L. (2013). Pengaruh Corporate Governance Preception Index (CGPI), Struktur Kepemilikan, dan Ukuran Perusahaan Terhadap Kinerja Keuangan. Jurnal 
Bisnis Dan Ekonomi, 20(2), 171-183. https://doi.org/10.1017/CBO9781107 415324.004

Jensen, M. C., \& Meckling, W. H. (1976). Theory of the firm: Managerial behavior, agency costs and ownership structure. Journal of Financial Economics, 3(4), 305-360. https://doi.org/10.1016/0304405X(76)90026-X

Kao, M. F., Hodgkinson, L., \& Jaafar, A. (2019). Ownership structure, board of directors and firm performance: evidence from Taiwan. Corporate Governance (Bingley), 19(1), 189216. https://doi.org/10.1108/CG-042018-0144

Kock, N. (2014). Advanced Mediating Effects Tests, Multi-Group Analyses, and Measurement Model Assessments in PLS-Based SEM. International Journal of E-Collaboration, 10(1), 113.

https://doi.org/10.4018/ijec.20140101 01

Kock, N., \& Lynn, G. S. (2012). Lateral Collinearity and Misleading Results in Variance- Based SEM: An Illustration and Recommendations. Journal of the Association for Information Systems Vol., $\quad$ 13(7), 546-580. https://doi.org/10.1002/ctpp.1974014 0604

Kumar, P., \& Zattoni, A. (2015). Ownership structure, corporate governance and firm performance. In Corporate Governance: An International Review (Vol. 23, Issue 6, pp. 469-471). https://doi.org/10.1111/corg.12146

Maulana, I. (2020). Analisis Pengaruh Dewan Komisaris Independen, Kepemilikan Manajerial dan Kepemilikan Institusional Terhadap Kinerja Perusahaan Jasa Keuangan di Indonesia. Jurnal REKSA Rekayasa Keuangan, Syariah, Dan Audit, 7(01), 11-23.

McColgan, P. (2001). Agency theory and corporate governance: a review of the literature from a UK perspective. Department of Accounting and Finance University of Strathclyde, May, 0-44.

Meah, M. R., \& Chaudhory, N. U. (2019). Corporate Governance and Firm's Profitability: An Emerging Economybased Investigation. Indian Journal of Corporate Governance, 12(1), 71-93. https://doi.org/10.1177/09746862198 36544

Mufidah, N. M., \& Purnamasari, P. E. (2018). Pengaruh Profitabilitas Terhadap Nilai Perusahaan Dengan Pengungkapan Corporate Social Responsibility Dan Good Corporate Governance Sebagai Variabel Moderating. El Dinar:Jurnal Keuangan Dan Perbankan Syariah, 6(1), 64-82. https://doi.org/10.18860/ed.v6i1.5454

Nakano, M., \& Nguyen, P. (2013). Foreign ownership and firm performance: Evidence from Japan's electronics industry. Applied Financial Economics, 23(1), 41-50. https://doi.org/10.1080/09603107.201 2.705425

Omran, M. M., Bolbol, A., \& Fatheldin, A. (2008). Corporate governance and firm performance in Arab equity markets: Does ownership concentration matter? International Review of Law and Economics, 28(1), 32-45.

https://doi.org/10.1016/j.irle.2007.12. 001

Rashid, M. M. (2020). Ownership structure and firm performance: the mediating role of board characteristics. Corporate Governance (Bingley), 20(4), 719-737. https://doi.org/10.1108/CG-02-20190056

Ren, H., Chandrasekar, K., \& Li, B. (2012). Moderating effects of board and managerial incentive on the relationship between $R \& D$ investment and firm performance- Evidence from 
listed manufacturing firms in China. The Journal of International Management Studies, 7(1), 41-55.

Shan, Y. G. (2019). Managerial ownership, board independence and firm performance. Accounting Research Journal, 32(2), 203-220. https://doi.org/10.1108/ARJ-09-20170149

Shleifer, A., \& Vishny, R. W. (2007). A survey of corporate governance. In Corporate Governance and Corporate Finance: A European Perspective (Vol. 52, Issue 2, pp. 52-90). https://doi.org/10.4324/97802039401 36

Singh, A., \& Kansil, R. (2018). Institutional ownership and firm performance: evidence from Indian panel data. International Journal of Business and Emerging Markets, 10(3), 250. https://doi.org/10.1504/ijbem.2018.10 013055

Solimun, Fernandes, A. A. R., \& Nurjannah. (2017). Metode Statistika Multivariat Pemodelan Persamaan Struktural (SEM) Pendekatan WarpPLS. UB Press.

Sugianto, S., \& Sjarief, J. (2018). Analisis Pengaruh Kepemilikan Manajerial, Proporsi Dewan Komisaris Independen, Dan Konservatisme Akuntansi Terhadap Kualitas Laba Serta Pengaruhnya Terhadap Nilai Perusahaan. Jurnal Akuntansi, 12(1), 80-103.

https://doi.org/10.25170/jara.v12i1.59

Sugiyono, P. D. (2017). Metode Penelitian Bisnis: Pendekatan Kuantitatif, Kualitatif, Kombinasi, dan R\&D. CV. Alfabeta.

Tsouknidis, D. A. (2019). The effect of institutional ownership on firm performance: the case of U.S.-listed shipping companies. Maritime Policy and Management, 46(5), 509-528. https://doi.org/10.1080/03088839.201 9.1584408
Tulung, J. E., \& Ramdani, D. (2018). Independence, size and performance of the board: An emerging market research. Corporate Ownership and Control, 15(2-1), 201-208. https://doi.org/10.22495/cocv15i2c1p 6

Westman, H. (2011). The impact of management and board ownership on profitability in banks with different strategies. Journal of Banking and Finance, 35(12), 3300-3318. https://doi.org/10.1016/j.jbankfin.201 1.05 .013

Wibowo, E. (2010). Implementasi Good Corporate Governance di Indonesia. Jurnal Ekonomi Dan Kewirausahaan, 10(2), 129-138.

Wijaya, L. I., Welson, \& Murhadi, W. . (2020). Ownership Structure, Good Corporate Governance, and Firm Performance in the Indonesian Capital Market. Advances in Economics, Business and Management Research, 115(17th International Symposium on Management (INSYMA 2020)), 256260.

Yavas, C. V., \& Erdogan, S. B. (2017). The effect of foreign ownership on firm performance: Evidence from emerging market. Australian Academy of Accounting and Finance Review, 2(4), 363-371.

Yeh, C. M. (2019). Ownership structure and firm performance of listed tourism firms. International Journal of Tourism Research, 21(2), 165-179. https://doi.org/10.1002/jtr.2250 